\title{
A "Ciência" do Egoísmo: breves críticas ao direito e ao homem (do) direito
}

\author{
Tayson Ribeiro Teles ${ }^{1}$
}

\begin{abstract}
Resumo: Neste artigo, com certo caráter ensaístico-filosófico, pensa-se um pouco sobre o egoísmo humano como sendo uma das vigas mestras de existência e manutenção do atual Direito ocidental. Com suporte em pensamentos de autores diversos, pela metodologia da revisão bibliográfica qualitativa, comenta-se sobre exemplos de egoísmo no Direito de um modo geral, sobre egoísmos de "Homens do Direito" profissionais da dita "Ciência" Jurídica, e sobre egoísmos de "Homens Direitos", as pessoas comuns que obedecem cegamente às leis. As conclusões indicam que tanto os Homens Direitos como os Homens do Direito são desmedidamente egoístas, fato que colabora para que o Direito prossiga sendo aplicado em plasma de inenarrável egoísmo. Palavras-chave: Egoísmo; "Ciência" Jurídica; "Homem do Direito"; "Homem Direito".
\end{abstract}

\section{The "Science" of Selfishness: brief criticisms of the right and the man (of) right}

\begin{abstract}
In this article, with a certain essayistic-philosophical character, one thinks a little about human egoism as being one of the master beams of existence and maintenance of present Western law. Based on the thoughts of several authors, the methodology of the qualitative bibliographical review refers to examples of egoism in the Law, in general, about selfishness of "Law Men" - professionals of this "Legal Science", and about selfishness of "Men Rights," ordinary people who blindly obey the laws. The conclusions indicate that both the Rights Men and the Men of the Law are exceedingly selfish, a fact that contributes for the Law to continue being applied in plasma of unspeakable selfishness.
\end{abstract}

Keywords: Selfishness; Juridical "Science"; "Man of Law"; "Right Man."

\section{La "ciência" del egoísmo: breves críticas al derecho y al hombre (del) derecho}

Resumen: En este artículo, con cierto carácter ensayista-filosófico, se piensa un poco sobre el egoísmo humano como una de las vigas maestras de existencia y mantenimiento del actual Derecho occidental. Con soporte en pensamientos de autores diversos, por la metodología de la revisión bibliográfica cualitativa, se comenta sobre ejemplos de egoísmo en el Derecho de un modo general, sobre egoísmos de "Hombres del Derecho" - profesionales de dicha "Ciencia" Jurídica, y sobre egoísmos de "Hombres Derechos", las personas comunes que obedecen ciegamente a las leyes. Las conclusiones indican que tanto los Hombres Derechos como los Hombres del Derecho son desmedidamente egoístas, hecho que colabora para que el Derecho prosiga siendo aplicado en plasma de inenarrable egoísmo.

Palabras clave: Egoísmo; "Ciencia" Jurídica; "Hombre del Derecho"; "Hombre Derecho".

\footnotetext{
${ }^{1}$ Mestre em Linguagem e Identidade (Cultura e Sociedade) pela Universidade Federal do Acre - UFAC (2016). Especialista em Gestão de Políticas Públicas pela Universidade Federal de Ouro Preto - Minas Gerais (2016). Graduado em Finanças pela UniSEB, de Ribeirão Preto - SP (2013). Licenciado em Matemática pelo Ceuclar-SP (2015). Bacharel em Direito pela UFAC (2017).
} 


\section{Introdução}

Puro egoísmo é quando os soberanos vivem em suntuosos palácios, enquanto os campos jazem desertos e vazios os celeiros. Puro egoísmo é ostentar roupas luxuosas, ufanar-se de armas, acumular riquezas às custas dos outros.

Lao-Tsé

As origens de nosso atual Estado democrático de Direito margeiam o estabelecimento do individualismo. De modo contraditório, os ideais burgueses, no auge do fronte das revoluções liberais contra o absolutismo, se resumiam-se, mesmo que implicitamente, ao alavanque da volição dos burgueses por condições de vida social iguais às dos reis, clérigos e nobres. O igualitarismo buscado, hoje se tem certeza, não era no sentido fraternal, mas somente na direção do usufruto das mesmas prerrogativas, dos mesmos privilégios e demais idiossincrasias elitistas vigorantes até aquele momento.

Dessa forma, por certo, o atual egoísmo estabelecido entre os homens no ocidente tem muito a ver com o processo histórico de formação da presente sociedade ocidental. $\mathrm{O}$ homem pós-moderno ocidental hodierno mescla, em seu dia a dia, uma benevolência para com o outro e um egoísmo imensurável para consigo mesmo. Para uns, tal comportamento não é de somenos relevância, pois é preciso pensar nos outros, mas, sobretudo, antes de qualquer coisa, em si mesmo, diz-se - algo análogo à ideia de Smith sobre haver no homem duas paixões imbricadas: benevolência e auto-interesse.

O objetivo do artigo que ora se apresenta é servir como mais um texto colaborador dos/nos debates sobre a pivotal necessidade de o atual Direito ocidental lastrear-se sobre diferentes paradigmas existenciais in faciem de suas atuais bases egoísticas. A justificativa acadêmica para a consecução do texto refere-se ao fato de que, frente ao egoísmo, a humanidade precisa de comportamentos mais coletivos para que as conquistas sociais auferidas sejam sempre em benefício de todos, ou, pelo menos, da maioria, comportamentos tais que serão obtidos com o tempo e pela educação, pelo ensino de novas formas de enxergar o Direito. A partir disso, o problema desenvolvido no texto é o seguinte: de que formas os Homens Direitos - os cidadãos que obedecem às leis - e os Homens do Direito - os profissionais que produzem e aplicam o Direito - são egoístas atualmente? Problemática tal que se tenta responder com suporte em pensamentos de autores diversos, pela metodologia da revisão bibliográfica qualitativa. 
Sabe-se ser complexo universalizar, dizendo que todos os homens são egoístas. Mas, é certo que se não somos todos, pelo menos a maioria de nossos problemas tem como motivo de ser o egoísmo de muitos, de vários homens. Grande parcela da atual população do mundo é egoísta, somente pensa em si, e não se pode velar esse fato. Vivem todos a pensar apenas em seus objetivos, anseios, desejos, volições, sonhos, e para realizrealizalosar todos estes não medimos o limite de nossas ações diárias.

Maltratamos nossos semelhantes, exploramos e magoamos pessoas. Queremos tudo para nós e nada ou pouco para os outros. Compromissos, selamos apenas conosco mesmos. Não nos comprometemos com ninguém, não confiamos em ninguém, olhamos sempre de ladinho. Vamos dizer palavras em público e iniciamos diccionando: "gostaríamos de saudar fulano, beltrano...”. Ora, quem gostaria não quer, não está fazendo. Vivemos apenas nosso mundo, não agimos no real, na vida práatica, em prol dos outros. Somos egoístas!

\section{Fundamentação Teórica}

\subsection{O Egoísmo e o Direito}

Segundo Schopenhauer (2001, p. 121), “o egoísmo é colossal, ele comanda o mundo. Se fosse dado pois a um indivíduo escolher entre a própria aniquilação e a do mundo, nem preciso dizer para onde a maioria se inclinaria”. Egoísmo este que, por ocorrer no mundo, à evidência, também ocorre no Direito e a partir dele. Para pensar sobre egoísmo e Direito, ao invés de empreender-se revisão de extensas teorias, escolheu-se, aqui, trazer à baila alguns exemplos práticos de egoísmos incrustados no Direito. Tais exemplificações objetivam clarificar de modo prático que o Direito não é melhor do que qualquer outro campo do saber, como propalam alguns "pseudojuristas".

De forma bruta e cruel, alguns aduzem que o Direito objetivador da melhoria de vida de todos, precipuamente dos hipossuficientes, é per se impraticável. Os que assim pensam, esclarecem que o projeto de emancipação da humanidade, concebido pelo Iluminismo, é inatingível, pois perpetrado pela legalização abstrata. De fato, a positivação jurídica intentada pelos burgueses objetivou garantir direitos antes inexigíveis em relação aos reis e poderosos. Todavia, o formalismo burguês encontrou mesmo a limitação do Estado como caminho para a igualação material das pessoas. Nesse foco, o caráter de dever-ser do Direito findou por alocar em elevado relevo o egoísmo de algumas classes, 
que resolveram usar as leis para buscarem benefícios particulares e indivisíveis com a maioria do povo, o que tem se estabelecido até os dias contemporâneos.

$A b$ initio, em primeiro exemplo de egoísmo no plasma da "Ciência" Jurídica, vejase a seguir capa de entrevista concedida em 2011 à Revista nacional "Visão Jurídica" pelo então presidente do Tribunal Regional Eleitoral do Mato Grosso do Sul, Desembargador Luiz Carlos Santini. Naquela época, o Desembargador concedeu entrevista para comentar sobre o início dos procedimentos de implantação da biometria e demais aspectos da "modernização" do sistema eleitoral no Mato Grosso do Sul. Usa-se, aqui, essa reportagem para exemplificar a visão dos membros do poder judiciário eleitoral pátrio sobre o sistema político nacional e a sua relação com o egoísmo humano.

\section{Imagem 1: Entrevista com Desembargador Eleitoral sobre compra de votos ${ }^{2}$}

CANAIS
Cartas

Comentando, na época, o implemento da biometria no Estado do Mato Grosso do Sul, sistema que hoje é uma realidade em quase todo o país, disse o magistrado de $2^{\circ}$ grau que jamais nenhum tipo de informatização dos sistemas de votação conseguirá eliminar a compra de votos por parte de alguns políticos, porquanto "os seres humanos são 'egoístas' e não pensam no País, mas em si mesmos".

Aduziu o magistrado que a compra de votos nunca vai acabar, porquanto sempre haverá alguém que aceita ser comprado e, por isso, sempre terá alguém para comprar. Obtemperou o juiz: “Todos nós somos altruístas, vaidosos, egoístas, é a natureza animal

${ }^{2}$ Disponível em: <http://revistavisaojuridica.uol.com.br/advogadosleisjurisprudencia/43/artigo158660-1.asp>. Acesso em: 10 fev. 2018. 
nossa. A grande virtude da sociedade é criar mecanismos para punir e, punindo, causar certo temor. Esse é o grande problema do Brasil”.

São interessantes argumentos, posto que, de facto, mesmo mecanismos eletrônicos não conseguem "adivinhar" se o eleitor vota por consciência ou se foi pago. Tem-se aí, no Direito Eleitoral, um cruel exemplo do egoísmo humano no Direito ou em sua relação com este. Ainda hoje, vários seres humanos vendem os seus votos por singelos objetos/valores, votos tais que, se somados todos, poderiam fazer grande diferença na mudança do status quo.

Prosseguindo nessa esteira do egoísmo no Direito, noutro exemplo, cita-se pesquisa realizada pelo Conselho Nacional de justiça (CNJ), no ano de 2011, sobre os tipos de pessoas que mais demandaram, naquele ano, no Judiciário brasileiro, sejam pessoas físicas, jurídicas, o Estado etc. A pesquisa não especifica se as pessoas mencionadas são demandantes ou demandadas, mas, mesmo sem tal informação, pode-se inferir muitas coisas. Observe-se o escorço dos dados da pesquisa:

Imagem 2: Pesquisa do CNJ sobre o acesso à justiça brasileira em $2011^{3}$

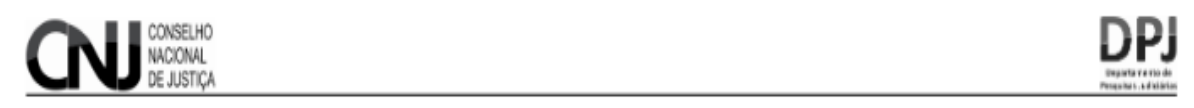

Listagem dos dez maiores setores contendo o percentual de processos em relação ao total ingressado entre $1^{\circ}$ de janeiro e 31 de outubro de 2011 por Justiça.

\begin{tabular}{|c|c|c|c|c|c|c|c|c|}
\hline \multirow{3}{*}{$\begin{array}{c}\text { Ordem } \\
1\end{array}$} & \multicolumn{8}{|c|}{ Setores dos Cem Maiores Litigantes } \\
\hline & \multicolumn{2}{|l|}{ Total } & \multicolumn{2}{|l|}{ Justiça Estadual } & \multicolumn{2}{|l|}{ Justiça Federal } & \multicolumn{2}{|l|}{ Justiça do Trabalho } \\
\hline & SETOR PÚBLICO FEDERAL & $12,14 \%$ & BANCOS & $12.85 \%$ & SETOR PÚBLICO FEDERAL & $83,18 \%$ & INDÚSTRIA & $2.03 \%$ \\
\hline 2 & BANCOS & $10,88 \%$ & SETOR PÚBLICO MUNICIPAL & $8,25 \%$ & BANCOS & $9,80 \%$ & SETOR PÚBLICO FEDERAL & $1,84 \%$ \\
\hline 3 & SETOR PÚBLICO MUNICIPAL & $6,88 \%$ & SETOR PÚBLICO ESTADUAL & $4,85 \%$ & CONSELHOS PROFISSIONAIS & $2,76 \%$ & BANCOS & $1,78 \%$ \\
\hline 4 & SETOR PÚBLICO ESTADUAL & $3,75 \%$ & SETOR PÚBLICO FEDERAL & $3,11 \%$ & SETOR PÚBLICO ESTADUAL & $0,56 \%$ & SERVIÇOS & $1,44 \%$ \\
\hline 5 & TELEFONIA & $1,84 \%$ & TELEFONIA & $2,38 \%$ & $O A B$ & $0,41 \%$ & COMERCIO & $0,83 \%$ \\
\hline 8 & COMÉRCIO & $0,81 \%$ & SEGUROS / PREVIDÉNCIA & $0,83 \%$ & SETOR PÚBLICO MUNICIPAL & $0,14 \%$ & SETOR PÚBLICO ESTADUAL & $0,88 \%$ \\
\hline 7 & SEGUROS / PREVIDÉNCIA & $0,74 \%$ & COMÉRCIO & $0,82 \%$ & SEGUROS / PREVIDÉNCIA & $0,06 \%$ & ASSOCIACOESS & $0,80 \%$ \\
\hline 8 & INDÚSTRIA & $0,83 \%$ & INDÚSTRIA & $0,44 \%$ & OUTROS & $0,06 \%$ & TELEFONIA & $0,80 \%$ \\
\hline 8 & SERVICOS & $0,53 \%$ & SERVICOS & $0,42 \%$ & EDUCACÁO & $0,04 \%$ & SETOR PÚBLICO MUNICIPAL & $0,45 \%$ \\
\hline 10 & CONSELHOS PROFISSIONAIS & $0.32 \%$ & TRANSPORTE & $0.18 \%$ & SERVICOS & $0,02 \%$ & TRANSPORTE & $0.40 \%$ \\
\hline
\end{tabular}

A pesquisa traz à baila a informação de que, percentualmente, as pessoas que mais integraram processos na justiça brasileira em 2011, seja como requerente (autor) ou requerido ("réu”), são, respectivamente, o setor público federal (o Estado/União e seus órgãos e instituições diversos), os bancos (públicos e privados) e a indústria.

Tais dados não podem servir de novidade ou surpresa a uma prudente interpretação do sistema jurídico nacional. O Estado sempre será muito demandado, posto que as

\footnotetext{
${ }^{3}$ Disponível em:

〈http://www.cnj.jus.br/images/pesquisasjudiciarias/Publicacoes/100_maiores_litigantes.pdf $>$. Acesso em: 10 fev. 2018.
} 
pessoas clamam por direitos que são obrigações deste a todo o momento, o qual, por pensar apenas em si (filosoficamente - o Estado é "invisível”), priva enorme parcela do povo de direitos in faciem dos perenes benefícios destinados às camadas privilegiadas (os "donos" do Estado).

No que pertine aos bancos, decerto, jamais querem perder (os banqueiros só pensam em seus lucros, logo, em si mesmos) e vão à justiça sempre que ameaçados de perder dinheiro em transações diversas, bem como os cidadãos comuns, também, sempre pensando em seus dinheiros (em si mesmos), buscam a justiça para demandar direitos em face de tais instituições bancárias. Quanto às indústrias, de igual modo, por ululante, são possuidoras de egoísmo (seus donos) e sempre integram polos em processos diversos, seja quando demandadas por trabalhadores, que reivindicam direitos relativos a extenuantes trabalhos industriais que desenvolvem, seja quando demandadas pelo Estado, por sonegação de tributos etc.

Essa pesquisa do CNJ, portanto, mostra que, numa perspectiva geral, as pessoas buscam o judiciário por motivos egoísticos. Existem algumas exceções, claro, como, por exemplo, ações civis públicas erigidas pelo Ministério Público, quando essa instituição busca proteger o meio ambiente, que é um bem coletivo; mas, até nestas, por vezes, existem promotores e procuradores egoístas, que apenas querem passar por proativos (combativos) para crescerem na carreira. Então, realmente, a maioria das ações que chegam aos protocolos do Judiciário pátrio envolvem algum tipo de demanda por recurso, notadamente econômico. O homem atual é egoísta e apenas age corretamente, sendo um "Homem Direito", a fim de enquadrar-se à lei, que foi feita (pelas elites, pelos "Homens do Direito") por ele mesmo, simplesmente, para beneficiar a si mesmo e à sua classe social. Esse é um fato inegável e não se pode dele fugir.

Nesse viés, estatística mais atual, também do CNJ, ratifica essas ideias. Eis os tipos de processos pelas áreas do Direito mais ocorrentes no Judiciário pátrio em 2015. No pódio, tem-se o Direito do Trabalho, em que há relações entre patrões e empregados por recursos diversos, quando cada um somente pensa em si e quer os seus bens e/ou direitos; o Direito Civil, em que há relações econômicas sociais diversas, sempre marcadas pelo interesse; e o Direito Tributário, em que há relações entre o Estado e empresas sonegadoras - que sonegam, querendo ganhar mais dinheiro, por exemplo. 
Imagem 3: Demandas mais recorrente na Justiça Brasileira em $2015^{4}$

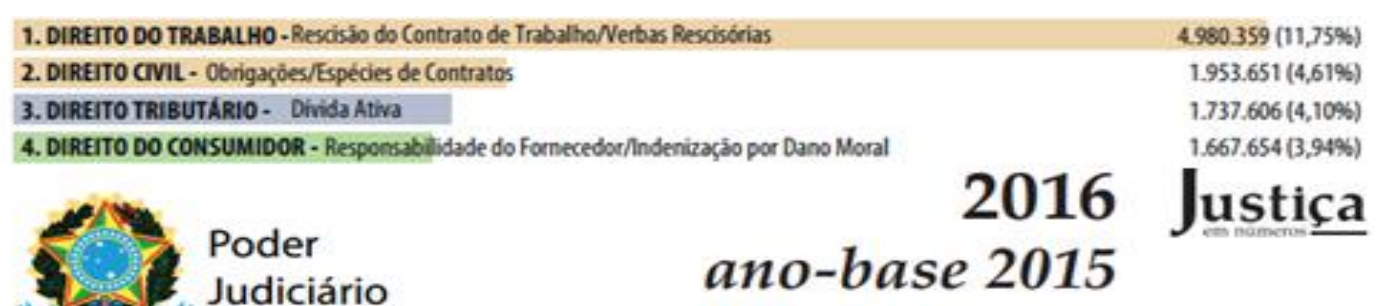

Nessa percepção, outra pesquisa interessante é o mais recente levantamento penitenciário geral do Brasil com relação aos presídios estaduais e federais, que foi feito pelo Departamento Penitenciário Nacional (DEPEN) do Ministério da Justiça, no ano de 2014. Segundo a pesquisa, o Brasil possuía, em 2014, pouco mais de 600 mil presos, o que faz de nós o quarto país do mundo com mais detentos, pois perdemos apenas para os EUA, a China e a Rússia - sendo que o nosso sistema prisional está em colapso, pois tem apenas 370 mil vagas e abriga quase o dobro de presos da capacidade.

Essa população prisional está aumentado cada vez mais, porquanto, em 1990, segundo o DEPEN, tínhamos 90 mil presos somente. Talvez o cometimento de crimes e, por conseguinte, a elevação do quantum de presidiários, tenha a ver com a "falta de educação" das pessoas. Atualmente, diz a pesquisa, 53\% dos presos brasileiros têm apenas o ensino fundamental completo. A pesquisa revelou, ainda, que a maioria dos tipos de crimes cometidos pelas pessoas é crimes contra o patrimônio. Os furtos, os roubos simples e os roubos qualificados ultrapassam os índices de homicídio simples. Assim, vê-se que o interesse econômico, o pensar apenas em si, em ter bens pra si, é um pilar do egoísmo humano, caractere que gera até crimes (roubos e furtos).

Observe-se o quadro que resume a pesquisa:

\footnotetext{
${ }^{4}$ Disponível em: <http://www.cnj.jus.br/files/conteudo/arquivo/2016/10/b8f46be3dbbff344931a933579915488.pdf>. Acesso em: 10 fev. 2018.
} 
Imagem 4: Pesquisa do DEPEN (2014) sobre o sistema prisional brasileiro ${ }^{5}$

Número de crimes tentados/consumados pelos quais as pessoas privadas de liberdade foram condenadas ou aguardam julgamento

\begin{tabular}{|c|c|c|c|}
\hline & Masculino & Feminino & Total \\
\hline Total de crimes & 234.524 & 11.297 & 245.821 \\
\hline \multirow[t]{2}{*}{ Código Penal } & 155.394 & 3.592 & 158.986 \\
\hline & Masculino & Feminino & Total \\
\hline Grupo: Crimes contra o patrimônio & 94.972 & 2.234 & 97.206 \\
\hline Furto simples (art. 155) & 14.284 & 456 & 14.740 \\
\hline Furto qualificado (art. $155, \S 4^{\circ}$ e $5^{\circ}$ ) & 12.829 & 403 & 13.232 \\
\hline Roubo simples (art. 157) & 16.449 & 224 & 16.673 \\
\hline Roubo qualificado (art. 157, $\S 2^{\circ}$ & 33.563 & 555 & 34.118 \\
\hline \multirow[t]{2}{*}{ Latrocínio (art. 157, § $3^{\circ}$ ) } & 6.639 & 182 & 6.821 \\
\hline & Mascullino & Feminino & Total \\
\hline Grupo: Crimes contra a pessoa & 38.731 & 874 & 39.605 \\
\hline Homicídio simples (art. 121, caput) & 13.529 & 352 & 13.881 \\
\hline Homicídio culposo (art. 121, § $3^{\circ}$ ) & 1.387 & 38 & 1425 \\
\hline Homicídio qualificado (art. 121, $\S 2^{\circ}$ ) & 17.764 & 355 & 18.119 \\
\hline
\end{tabular}

Ao observar tal quadro, somos levados a obter visão crítica sobre a essência do Direito. Cremos que ninguém processa outrem para cobrar uma dívida porque é "correto", é "direito" e/ou "busca seus direitos", mas porque é egoísta e quer o seu dinheiro apenas para si; bem como ninguém mata o amante de seu cônjuge ou companheiro(a) apenas por "vingança”, mas porque é egoísta e quer/queria o seu companheiro apenas para si; vários são os exemplos de “egoísmo jurídico humano”. Claramente, há exceções - nada é absoluto, mas, lato sensu, vige, no chamado "mundo jurídico", egoísmo inefável. Precisase mudar essa realidade e fazer do Judiciário um local de busca por direitos efetivamente relevantes, aqueles inerentes à cidadania, à saúde, à educação etc. Parece claro ser um fracasso humano, por exemplo, pessoas de uma mesma família atuarem em lados opostos em processo no Judiciário.

Para entronar que não se está criticando inocuamente a "Ciência" Jurídica, pois o tema egoísmo é, de fato, muito subjetivo, veja-se exemplo de uma decisão judicial em que o motivo do crime, segundo o juízo sentenciador, foi o egoísmo:

\footnotetext{
5 Disponível em: <http://www.justica.gov.br/noticias/mj-divulgara-novo-relatorio-do-infopen-nesta-tercafeira/relatorio-depen-versao-web.pdf>. Acesso em: 10 fev. 2018.
} 
EMENTA: APELAÇÃO-CRIME. HOMICÍDIO QUALIFICADO. MOTIVO FÚTIL E RECURSO QUE IMPOSSIBILITOU A DEFESA DA VÍTIMA. CONDENAÇÃO. IRRESIGNAÇÃO DEFENSIVA. APELO INTERPOSTO COM BASE EM TODAS AS ALÍNEAS DO INCISO III DO ARTIGO 593 DO CÓDIGO DE PROCESSO PENAL. NOVO JULGAMENTO. INVIABILIDADE. PENA MANTIDA. 1. Alínea a: Ausente nulidade a ser declarada. 2. Alínea d: Não se pode considerar o veredicto dos jurados manifestamente contrário à prova dos autos, pois que existe aqui seguimento probatório a confortar a conclusão alcançada pelo Conselho de Sentença, não só em relação à condenação, contra a qual não se insurge a defesa nas razões recursais, mas, também, no tocante ao reconhecimento das qualificadoras. 2.1. Motivo fútil. Foi levado à apreciação dos jurados se o fato de o apelante esfaquear a vítima por suspeitar que ela mantivesse relacionamentos amorosos extraconjugais configura a qualificadora do motivo fútil. [...]. De qualquer forma, ainda que fosse real a alegada traição, não mera "imaginação" do réu, ainda assim, não se pode dizer que a decisão dos jurados, ao reconhecer a futilidade da motivação do delito, é manifestamente contrária a prova dos autos, porquanto o motivo continua sendo o 'egoísmo intolerante, prepotente, mesquinho, que vai até a insensibilidade moral'. Verifica-se, aqui, que mais uma mulher foi vítima de um 'crime passional' há muito anunciado, mostrando-se inócua a intervenção Estatal, que deixou de avaliar a gravidade do caso concreto e de tomar medidas efetivas de proteção, como orientar a vítima quanto aos riscos e, também, submeter o próprio agressor a alguma terapia de mudança comportamental. 2.2. Recurso que impossibilitou a defesa da vítima. Durante a madrugada, quando todos dormiam (o adolescente no sofá da sala, e as demais no único quarto, sendo Geni com três filhos na cama de casal e a vítima com seus dois filhos na cama de solteiro), o réu empurrou a porta do quarto, que dava acesso aos fundos da casa, retirou a filha que estava nos braços da vítima e, na presença das crianças, desferiu o golpe no coração da vítima quando ela ainda estava deitada. [...]. Decisão mantida. ${ }^{6}$ (Grifos nossos)

Trata a ementa de pedido, realizado em 2014, de um réu condenado, por júri popular, por matar a sua companheira, no estado no Rio Grande do Sul, para que o seu julgamento fosse anulado, pelos diversos motivos que a sua defesa expendeu. Ao confirmar a sentença e não prover o recurso, o Tribunal de Justiça daquela unidade federativa, por meio do relator que proferiu o voto modelo, afirmou ter sido o crime cometido por egoísmo e ciúmes do réu.

No acórdão, o relator frisa que o egoísmo do condenado é intolerante, prepotente, mesquinho e que margeia a insensibilidade moral. O condenado matou friamente a sua companheira na frente de seus filhos (deles dois). Essa decisão é bem interessante, ainda, porque traz uma espécie de "desabafo" do relator, o qual aduz que o Estado falhou na

\footnotetext{
${ }^{6}$ Disponível em: <http://tj-rs.jusbrasil.com.br/jurisprudencia/130222760/apelacao-crime-acr-70052340601rs>. Acesso em: 10 fev. 2018.
} 
proteção à mulher morta, posto que poderia ter orientado a vítima sobre a sua relação ou poderia ter tomado medidas para tratar a violência contumaz do condenado, evitando o feminicídio. Tal "desabafo" também pode ser considerado um egoísmo do relator, que pensa apenas em seu poder (o Poder Judiciário) e de forma tranquila joga a culpa no Poder Executivo, pois ele é o responsável direto por erigir políticas públicas em prol do povo, cabendo ao Judiciário, em tese, apenas julgar demandas. Fica deveras fácil erigir lindas sentenças, votos e acórdãos, criticando os outros por falhas sobre as quais não se tem responsabilidade direta.

Crê-se que esse egoísmo presente no Direito brasileiro, em vários setores, aspectos e interfaces, tem origem ainda no encontro entre o europeu e o nativo. Infelizmente, foram nossos antepassados contaminados pela prepotência de superioridade dos europeus - os moradores lá da Europa, que somente se viu superior quando encontrou outros lugares e teve com quem se comparar. Em exemplo de norma recente tecida em plasma de contaminação do legislador pátrio com os ideais europeus moderno-burgueses, pegue-se a Constituição Federal de 1988.

Esta:

[...] foi o resultado de um conjunto de forças existentes no país, representadas pela classe média da sociedade. Refletiu o somatório da hegemonia ideológica da classe média tecnoburocrática [...]. Os interesses dos diversos seguimentos sociais, ao chegarem ao congresso, foram manejados de forma inadequada pelas comissões, o que não colaborou para que a Constituição fosse efetivamente representativa de toda a sociedade brasileira. Deve-se o resultado de tal desvio ao trabalho eficiente dos grupos organizados ligados direta ou indiretamente a interesses específicos, originando uma Carta corporativista, nacionalista, intervencionista e estatizante (KUJAWSKI, 2007, p. 14).

Sem ingresso no mérito/conteúdo do texto constitucional, observe-se apenas o preâmbulo da Carta Política de 1988. Comparemo-lo com o preâmbulo da Constituição de 1996 da África do Sul. Brasil e África do Sul, dois países com histórias parecidas, passados humilhantes, exploratórios, vexatórios. Veja-se as diferenças dos preâmbulos constitucionais:

Quadro 1: Preâmbulos da Constituição do Brasil e da África do Sul

\begin{tabular}{|l|l|}
\hline $\begin{array}{l}\text { Constituição da República Federativa do } \\
\text { Brasil de 1988 }\end{array}$ & $\begin{array}{l}\text { Constituição da República da África do Sul } \\
\text { de 1996 }\end{array}$ \\
\hline $\begin{array}{l}\text { Nós, representantes do povo brasileiro, } \\
\text { reunidos em Assembleia Nacional }\end{array}$ & $\begin{array}{l}\text { Nós, o povo da África do Sul, reconhecemos } \\
\text { as injustiças do nosso passado; honramos }\end{array}$ \\
$\begin{array}{l}\text { Constituinte, para instituir um Estado } \\
\text { Democrático, destinado a assegurar o o } \\
\text { exercício dos direitos sociais e individuais, a } \\
\text { aqueles que sofreram pela justiça e pela } \\
\text { liberdade, a segurança, o bem-estar, o }\end{array}$ & $\begin{array}{l}\text { liberdade em nossa terra; respeitamos } \\
\text { aqueles que trabalharam para construir e } \\
\text { desenvolver nosso país; acreditamos que a a }\end{array}$ \\
\hline
\end{tabular}




\begin{tabular}{|c|c|}
\hline $\begin{array}{l}\text { desenvolvimento, a igualdade e a justiça } \\
\text { como valores supremos de uma sociedade } \\
\text { fraterna, pluralista e sem preconceitos, } \\
\text { fundada na harmonia social e comprometida } \\
\text { com a solução pacífica de controversas, } \\
\text { promulgamos, sob a proteção de Deus, a } \\
\text { seguinte Constituição da República } \\
\text { Federativa do Brasil (BRASIL, 1988). (Grifos } \\
\text { nossos) }\end{array}$ & $\begin{array}{l}\text { África do Sul pertence a todos que aqui } \\
\text { moram, unidos em nossa diversidade. Nós, } \\
\text { portanto, através de nossos representantes } \\
\text { eleitos livremente, adotamos esta } \\
\text { Constituição como lei suprema da República } \\
\text { de forma a: curar as divisões do passado e } \\
\text { estabelecer uma sociedade baseada em } \\
\text { valores democráticos, justiça social e direitos } \\
\text { humanos fundamentais; lançar as bases para } \\
\text { uma sociedade aberta e democrática na qual } \\
\text { o governo é baseado no desejo do povo e } \\
\text { todos os cidadãos são igualmente protegidos } \\
\text { pela lei; melhorar a qualidade de vida de } \\
\text { todos os cidadãos e libertar o potencial de } \\
\text { cada pessoa; e construir uma África do Sul } \\
\text { unida e democrática, capaz de tomar seu } \\
\text { lugar de direito como Estado soberano na } \\
\text { família das nações. Que Deus possa } \\
\text { proteger o nosso povo. (ÁFRICA Do SUL, } \\
\text { 1996) Grifos nossos). }\end{array}$ \\
\hline
\end{tabular}

Observemos as dessemelhanças. O texto sul-africano soa humildade, esperança, ternura. Em seu final, os constituintes daquele país dizem esperar que Deus possa (se ele quiser/puder) proteger a África do Sul. No preâmbulo brasileiro, os constituintes, em sua maioria aristocratas, donos de terras, industriais etc., achavam-se tão bons que, para eles, era certo que Deus os protegia, é tanto que afirmaram estar promulgando a Constituição de 1988 sob a proteção de Deus. Como podia Deus não proteger aqueles "homens bons"? Quanto egoísmo! Meu Deus!

Os constituintes brasileiros foram formalistas em demasiado em nosso preâmbulo. Eles autodeclaram-se os responsáveis pelo fabrico da nova Constituição. Disseram que eles, os "representantes do povo", estavam promulgando a Constituição. Os parlamentares sul-africanos, de forma diferente, usaram o "nós" efetivamente como terceira pessoa. O "nós" do preâmbulo brasileiro cheira à prepotência, soberba, arrogância.

Além disso, é deveras emotivo o texto preambular sul-africano. Nele, enxerga-se o real processo histórico que levou à feitura da Constituição de 1996. Os parlamentares brasileiros nem sequer cogitaram tocar no sofrido passado pátrio ao promulgar a nova lei máxima. Talvez a assunção dos erros pretéritos de nosso Direito, de nossa "Ciência" Jurídica, possa servir de caminho à busca de novos paradigmas que sejam distanciados da indolente razão da modernidade, como prega Boaventura de Sousa Santos (2001). 


\subsection{O Egoísmo do "Homem do Direito"}

Hodiernamente, os "Homens do Direito", ou seja, os profissionais que lidam direta e diariamente com o Direito, são inefavelmente egoístas. O juiz, geralmente, só pensa em si, em sua carreira, ao querer pôr termo a todos os feitos de sua comarca, para lograr ser promovido à capital de seu estado por "merecimento". Às vezes, vive frustrado por ter de aplicar leis ridículas e/ou injustas.

O promotor, geralmente, só pensa em si ao crer ser a sua "denúncia" a verdade real dos fatos e uma verdadeira "denúncia da sociedade", que ele alega "representar", mesmo que, algumas vezes, ele tenha sido um "filhinho de papai" que nunca passou fome. O procurador também é egoísta e somente pensa em si e em seu salário, pois, ao representar o Estado, a União, o Município, a autarquia ou o poder a que é subordinado, na medida em que não representa os seus objetivos pessoais, mas de outros, só pode agir primordialmente motivado pelo salário ou pelo status do cargo.

Veja-se a seguir um notável exemplo de egoísmo de um "Homem do Direito". O juiz federal Sérgio Fernando Moro, da Justiça Federal do Paraná, juiz responsável pela conhecida “Operação Lava Jato". Ainda no começo de 2014, o magistrado costumava intimar a defesa de seus réus por telefone, a fim de ganhar tempo e prazos, que seriam mais extensos caso as intimações fossem levadas a efeito por meio eletrônico ou Oficial de Justiça.

O que levou o juiz a intimar por telefone? Onde está isso na legislação? Pensou em encerrar agilmente os seus processos, seja condenando ou inocentando, ou pensou, de fato, na sociedade, no devido processo legal, no direito de defesa? Como um juiz tão respeitado por suas atitudes "anti-corruptivas" nega-se a cumprir simples regras processuais de prazos? Isso não é corromper-se pela pressa, pelo egoísmo? 


\section{Imagem 5: Notícia sobre atuação de Sérgio Moro ${ }^{7}$}

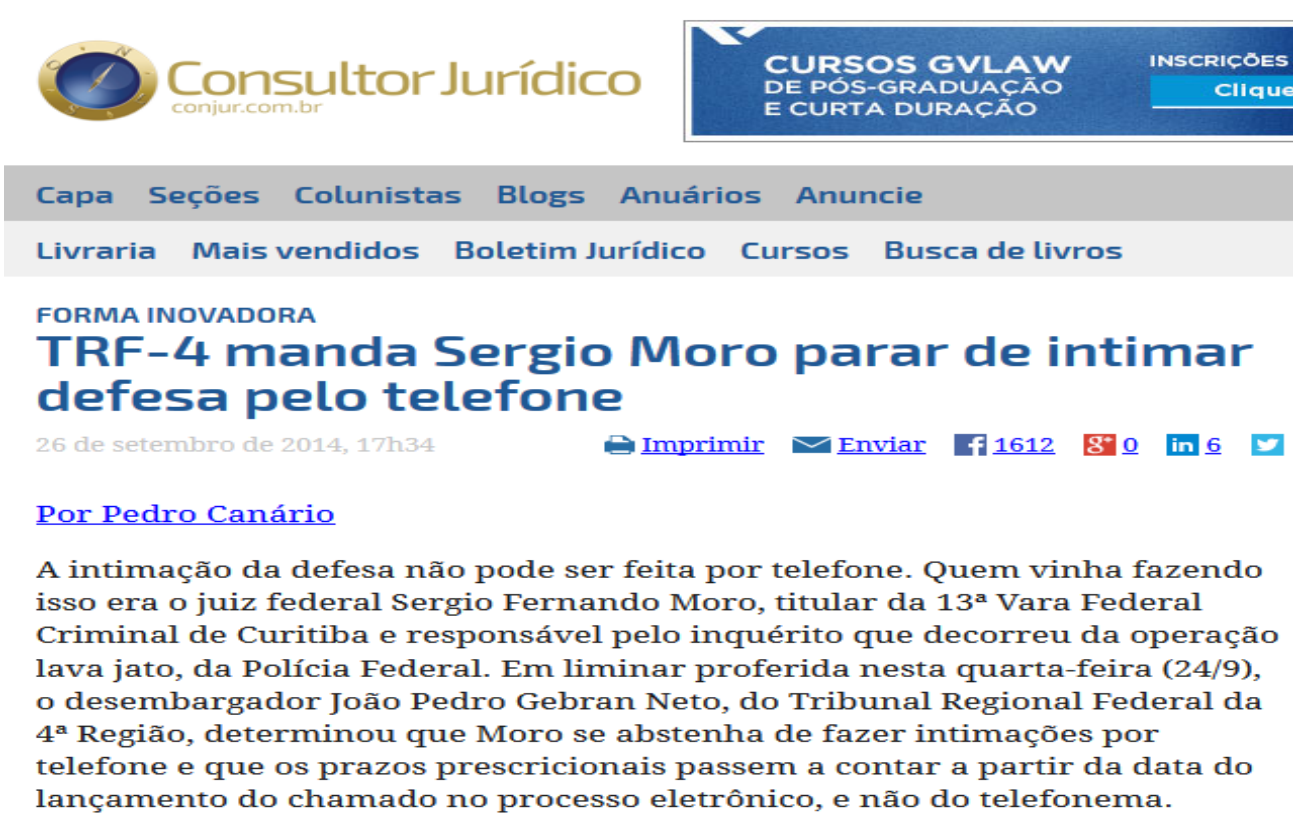

Foi preciso um advogado de um dos réus da dita "Operação Lava Jato" ingressar com ação judicial junto ao Tribunal Regional Federal ao qual se vincula Sérgio Moro para que este parasse de intimar por telefone. Alguns comportamentos de Moro são problemáticos e chegam a ferir mortalmente nossa Constituição de 1988. Não defendemos aqui corruptos, mas o Direito justo, aquele que segue o rito, os prazos, que somente condena com provas cabais, irrefutáveis, verossímeis. Afinal, se fulano diz que beltrano roubou X junto com ele e não há provas, não podemos por tal beltrano na cadeia por mais de 20 anos e livrar fulano só porque ele "dedurou" beltrano. Não se faz sentenças com ilações ou apenas testemunhos!

Não interessa se beltrano roubou mesmo. Se roubou, ele entender-se-á com a sua consciência. Embora a lei deva sempre ser cumprida, temos em nosso país o fulcral princípio do in dubio pro reu e a imprescindível necessidade de provas. Parecem frias nossas palavras, mas somente saberemos a importância desse princípio se um dia formos acusados de algo sendo inocentes. Pelo menos, imaginemos isso e, logo, veremos a força desse axioma.

Cremos que algumas decisões de Moro, no engendro das quais ele deixa-se levar por terceiros, notadamente, a mídia elitista, desequilibra a sociedade, pois “[...] os clamores dos grupos sociais, que são facilitados pela internet, funcionam como [...] pressão sobre os poderes legislativo e judiciário, o que provoca [...] a promulgação de leis que não refletem

7 Disponível em: <http://www.conjur.com.br/2014-set-26/trf-manda-sergio-moro-parar-intimar-defesatelefone>. Acesso em: 11 fev. 2018. 
[...] o interesse [...] da população e o desequilíbrio das decisões judiciais" (ABREU, 2015, p. 136).

Vivemos um período no Brasil onde está sendo instaurada uma espécie de “positivismo dos ideais da mídia e das elites". Ideias extremamente conservadoras são propaladas na internet, as pessoas movimentam-se, invocam Deus, gritam palavras de patriotismo, vão às ruas e querem a todo custo cumprir tais ideias. Pessoas várias, inclusive alguns ditos intelectuais, vão à rua protestar contra o governo, sob a alegação de corrupção, vestidas com camisas das CBF (Confederação Brasileira de Futebol), logo da CBF (?). Agem como se fazia na época célebre do positivismo: sem ver o conteúdo das indicações, das ações, das normas. Vão com os outros. Não estudam história.

Nesse contexto, são relevantes os comentários de Abreu (2015, p. 149) sobre outro "Homem do Direito" pátrio em "destaque" atualmente, o procurador da República Deltan Dallagnol, o chefe da "Operação Lava Jato":

\begin{abstract}
Entre os juízes, cresce a fundamentação de sentenças com base na Bíblia. Neste contexto, é sintomático que o Procurador da República Deltan Dallagnol, coordenador da Operação Lava Jato, na qual sob o mote do combate à corrupção, têm sido utilizadas medidas de legalidade duvidosa, como prisões preventivas de duração indefinida e utilização irrestrita do instituto da delação premiada, tenha declarado aos participantes de um culto: 'Dentro de minha cosmovisão cristã, eu acredito que existe uma janela de oportunidade que Deus está dando para mudanças' (LEITE, 2015). A história já demonstrou, repetidas vezes, as consequências desastrosas de se deixar a vida coletiva ser conduzida por pessoas que acreditam exercer uma missão sagrada.
\end{abstract}

Concordamos com Abreu e não estamos dizendo que pessoas públicas com poder de decisão não devem se deixar influenciar por nada provindo da sociedade ou que não podem seguir alguma religião, não! Por óbvio, algumas influências devem ser permitidas, notadamente as que se direcionam a instigar as autoridades a tomarem atitudes verdadeiramente em prol do bem comum, do bem de todos, absolutamente todos. O que é ruim são influências negativas, planejadas pela mídia e pelas elites de forma escusa.

O resto, as influências "positivas" devem ser enaltecidas, posto que são uma importante arma dos pobres, ainda pouco representados nas elevadas esferas de poder. Nesse prisma, não deve o "Homem do Direito" endeusar-se tanto a ponto de não lembrar que os outros podem ajudar-lhe em seu trabalho, em sua função, na propagação de seu “discurso jurídico". Uma pessoa só, um juiz, um procurador, não muda o mundo, a história. Não precisamos de heróis, pois somos todos fortes, bem como o discurso de que 
alguém tem de começar o serviço de "limpar o Brasil" também é falho, repleto de lacunas. Por acaso, não pode o povo iniciar uma revolução, um movimento com verdadeira consciência política? Somente uma pessoa com poder estatal pode fazê-lo? Apenas podemos mudar as coisas via sentenças judiciais mandamentais? Tudo é relativo, nada é absoluto. A influência é importante, mas somente se bem usada ${ }^{8}$.

Ademais, o egoísmo do "Homem do Direito" pátrio pode ser demonstrado de outras várias formas. Essas citações que se fez ao juiz Sérgio Moro e ao procurador Dallagnol foram apenas para demonstrar que, efetivamente, no fundo do fundo da vida juris brasileira, os agentes diversos da justiça pátria apenas pensam em si, em seus prazos, suas reputações, suas ações, seus atos. Até mesmo os que alegam pensar no todo, em todos, são egoístas por pensar que os seus modos de pensar no bem comum são os melhores modos. É preciso obliterar algumas atitudes claramente equivocadas e contrárias à Fumus boni juris - Fumaça do bom Direito. O Direito somos todos nós. Todos.

Mais um exemplo de egoísmo dos "Homens do Direito": os juízes, procuradores, delegados etc., notadamente os "federais", em sua maioria, são elevadamente egoístas ao acharem-se mais competentes ou mais inteligentes que outros profissionais, juristas ou não, estaduais e municipais. Creem haver "hierarquias sociais" na república brasileira. Será mesmo que é impossível um profissional do Direito pensar: o meu sonho é ser analista do INSS (Instituto Nacional do Seguro Social), trabalhar com os idosos etc., ao invés de pensar em cargos com maiores salário, poder e status?

Juízes, delegados e procuradores federais (a maioria deles ${ }^{9}$ ) logo quando passam nos seus concursos respectivos olham para si mesmos e dizem: somos os melhores. Estudamos mais, somos mais dedicados, "merecemos" mais. Essa é a meritocracia ridícula impregnada nas mentes dessas pessoas, a qual faz elas esquecerem que outras pessoas não "vencem" porque não têm acesso aos mesmos recursos, mesmas oportunidades que elas ou porque simplesmente não querem fazer parte do putrefato mundo do Direito, e não porque

\footnotetext{
${ }^{8}$ No caso dos "Homens do Direito" da tipologia parlamentar, por exemplo, precisamos ter em mente que "o discurso jurídico não se limita ao que é dito pelos auto-intitulados 'operadores do Direito', abrangendo as representações sociais de não especialistas. Godinho lembra que a elaboração de qualquer lei passa por uma '[...] fase pré-jurídica, que é nitidamente política, voltada à construção das regras e institutos do Direito [...]' (2012, p. 184), na qual interferem os '[...] movimentos sociopolíticos e correntes político-filosóficas que provocam e condicionam a elaboração normativa' (2012, p. 184). A luta política tem como fundo o desejo de cada grupo social de que suas normas morais tornem-se normas jurídicas, de observância obrigatória pelo conjunto da população" (ABREU, 2015, p. 138).

${ }^{9}$ Para evitar ferir egos, frise-se: maioria não é igual a todos.
} 
são "burras". Existe todo um contexto, uma história, um sistema (capitalista). Existem escolhas, caminhos, vidas. Todas as pessoas são únicas.

É certo que:

A crença mais forte de um grupo é a convicção compartilhada entre seus integrantes da própria superioridade grupal, que pode ser detectada com facilidade no discurso meritocrático, com o qual membros dos grupos sociais privilegiados se autoglorificam recorrendo a argumentos diversos como a vontade divina, sua constituição biológica ou esforço individual por eles despendido (ABREU, 2015, p. 137).

Precisamos ser sinceros. Vamos às universidades, por exemplo, lá a maioria dos alunos de Direito elogiam docentes que são juízes, promotores, procuradores federais em face do ostracismo social que infligem aos outros que apenas são professores, pesquisadores mestres/doutores ou outra coisa. Será mesmo que a sua profissão e quanto você ganha diz se você é um bom profissional, uma boa pessoa?

Os administradores da coisa pública também podem ser vistos como "Homens do Direito", posto que lidam diariamente com normas e estão imersos dentro do Estado. Tais administradores também são egoístas. Os "Homens do Direito" da tipologia parlamentar, por exemplo, erigem comportamentos desmedidamente egoísticos. Como afirmaria Foucault (2014), fazem na cara mesmo, jogam os seus discursos em nossas caras, na "lata", no escárnio da cretinice, falsidade e putrefação dos valores humanos mais prudentes.

No:

[...] cenário político brasileiro contemporâneo, marcado por um crescente conservadorismo [...] a lei, apesar de seu caráter geral, isto é, de destinar-se a todos, muitas vezes tem servido para defender valores que são caros apenas a estratos populacionais específicos, o que compromete o princípio da impessoalidade e ofende o pluralismo político, que é um dos fundamentos da República brasileira (ABREU, 2015, p. 136-137).

Vivemos em um país onde a maioria de nossos "Homens do Direito" parlamentares estão envolvidos com crimes, escândalos, esquemas de corrupção. Mais de 300 de nossos 513 Deputados Federais possuem algum tipo de processo judicial pendente. $70 \%$ dos Senadores que recentemente processaram e depuseram Dilma Rousseff têm algum tipo de processo criminal tramitando contra si. Como expressou Renato Russo: “Que país é esse?”. O Brasil tem "[...] caráter formal de [...] democracia, onde a opulência de uma minoria [parlamentar] contrasta com a falta de condições materiais da maioria, o que fere de morte o princípio da dignidade da pessoa humana, fundamento maior da Carta Magna” (ABREU, 
2016, n.p.). E, com efeito, o problema não está apenas nesses parlamentares, está em todos nós, todos, todas as instituições e pessoas.

Devemos alertar para o fato de que:

\begin{abstract}
A instabilidade política que o país atravessa, entretanto, não é o resultado de práticas isoladas dos deputados brasileiros e dos meios de comunicação, mas de um concerto de ações, para o qual concorrem funcionários de órgãos estatais diversos, como o Poder Judiciário, o Ministério Público e a Polícia Federal, e setores da população identificados com o conservadorismo, responsáveis pela eleição da 'bancada BBB: boi, bala, bíblia' (MARTINS, 2015). O propósito comum de todos esses atores é a tentativa de impor ao conjunto da população um projeto de hegemonia fundamentado numa visão de mundo excludente e antidemocrática, na qual mitos como o da meritocracia ocupam posição de destaque (ABREU, 2016, n.p.).
\end{abstract}

Assim, cabe a todos nós, seja lá qual for nosso nível de instrução, refletirmos sobre nosso atual Estado e nossa sociedade. Não podemos deixar que destruam nosso Brasil, nosso Direito, nosso plexo de possibilidades de políticas públicas estampado na Constituição Federal de 1988 e as suas leis infraconstitucionais. Precisamos alavancar o bom senso, a obviedade da positividade presente no agir coletivo, na filantropia, na comunês das coisas.

\title{
2.3 O Egoísmo do "Homem Direito"
}

Tratemos um pouco de alguns exemplos genéricos de egoísmo "no" Direito, do egoísmo dos "Homens do Direito", mas e quanto aos "Homens Direitos"? Essa tipologia de homem representa a maior parte do povo que se declara fiel obedecedor de leis provenientes de mentes de parlamentares integrantes das elites ou financiados por elas; o Homem Direito é o homem que cumpre leis pela comodidade da sensação de estabilidade que a passividade provoca, bem como porque apenas pensa em si, em sua família, em sua casa, em seu trabalho, em sua segurança, sua saúde. São os homens comuns, que cumprem as leis independentemente de seus conteúdos. Eles obedecem às normas por medo de serem punidos, de perderem os seus bens, ou seja, por puro egoísmo. Tais homens retos não percebem, porém, que, em verdade, todas as instituições e normas às quais se prostram são seus algozes diários. A família, a escola, a igreja, o Estado, tudo tem o escopo de controlá-los, enquadrá-los, sufocá-los sutilmente. Tais homens não conseguem enxergar- 
se como protagonistas de suas vidas, de seu tempo, da história e agir, buscar mudanças, nem que seja por dentro do próprio sistema que os encobre ${ }^{10}$.

Nesse tonário:

\begin{abstract}
A ausência de senso de protagonismo histórico na grande maioria das pessoas é causada, sobretudo, pela dominação simbólica, 'inscrita em toda a ordem social e operando na obscuridade dos corpos' (BOURDIEU, 2011, p. 99), que se exerce mediante a ação de instâncias normativas diversas, como a família, as religiões em geral, o sistema escolar, o Estado e os veículos de comunicação de massa (ABREU, 2016, n.p.).
\end{abstract}

Então, qual a solução para o egoísmo do "Homem Direito"? Ele deve parar de ser “direito", cessando seu obedecimento às leis? Certamente, não. Cremos ser preciso que tal homem desperte sempre que se deparar com regras que se afigurem como desproporcionais, que tendam a eliminar desejos/direitos dos mais pobres, que queiram cercear os direitos fundamentais de que dispõe tal homem apenas por estar vivo, como o direito à saúde, à educação, à felicidade, à segurança. Deve o homem prudente não apenas obedecer às leis, porque tal ato é bonito, é o padrão, é confortante internamente, mas também porque tais leis são boas, agradáveis, perfectibilizadoras de benefícios para todos.

Todavia, como pensar assim se as leis são erigidas pelos poderosos, os quais, à evidência, tendem sempre a produzir regras que lhes beneficiem em face dos pobres? É preciso tomar o poder? Eleger apenas pessoas pobres para o Congresso Nacional, no caso do Brasil? Cremos que, mesmo se fosse crível, não é a solução. Pensamos talvez ser interessante, num futuro utópico que nos alimenta a alma, haver algum mecanismo propiciador de certo tipo de regulação do povo às leis que tratem de temas sensíveis, por meio de algum "referendo legislativo". Não como os atuais, em que são gastos milhões para que os cidadãos vão às urnas, mas, de algum modo, menos oneroso, talvez por internet, com chaves de segurança, assinaturas digitais, algo assim.

Um efetivo controle pelos cidadãos sobre as leis que estejam sendo confeccionadas nos parece interessante na medida em que largar o "osso do poder" não parece ser atitude que integra o cabedal de planos dos poderosos. Esses poderosos que atualmente caminham rumo a "neoliberalizar" totalmente o Brasil, com reformas perversas nas áreas trabalhista, previdenciária, entre outras. Essa ideia parece-nos interessante quando nos lembramos de Rousseau e seu hipotético, para alguns fantasmagórico, “contrato social”.

\footnotetext{
${ }^{10}$ Dizemos tal homem, mas também nos enquadramos nesta categoria de homens retos (cegos). Estamos ainda engatinhando em nossas compreensões filosóficas sobre o Direito, sobre a vida.
} 
Como nos lembra Sena (2011, p. 84):

\begin{abstract}
Rousseau diz que a liberdade está inerente na lei livremente aceita, porque seguir o impulso de alguém é escravidão, porém obedecer uma lei auto-imposta é liberdade, pois a liberdade é um direito e um dever ao mesmo tempo. A liberdade lhes pertence e renunciar a ela é renunciar à própria qualidade de homem. Portanto, o homem ao ganhar a sua liberdade civil ele tem os mesmos direitos que o outro e, o Estado por sua vez deverá preservar os direitos a todos de forma igualitária para não haver privilegiados. (Grifos nossos)
\end{abstract}

É interessante pensarmos em um controle legislativo engendrado pelo povo. Contudo, devemos, também, ter em mente que é impossível que cada cidadão de uma nação diga se aprova ou não certa lei, pois sempre alguém não vota, bem como a maioria absoluta é impossível. Bem nos assinalou o jurista e revolucionário francês Joseph Emmanuel Sieyès, ainda no século XVIII: “O que é a vontade de uma nação? É o resultado de vontades individuais, como a nação é a reunião de indivíduos" (SIEYÈS, 2009, p. 79).

Vejamos a força dessa expressão. Sieyès faz-nos pensar que a maioria não é verdadeiramente a vontade de todos, mas somente a soma de vontades individuais, de pessoas únicas e irrepetíveis. Sieyès, entretanto, asseverou ser "[...] impossível conceber uma associação legítima que não tenha como objeto a segurança comum, a liberdade comum, enfim, a coisa pública" (SIEYÈS, 2009, p. 79). Em sua principal obra, Sieyès faz sugestões sobre como acreditava que deveria funcionar o Estado Francês do século XVIII. São curiosas as ideias desse revolucionário. Quando lembramos que ele era um aristocrata, rico e abastado político e, mesmo assim, teve ideias tão direcionadas ao povo, pensamos ser factível ainda crermos que existem, ou podem existir, homens públicos que pensem concretamente no bem comum.

Sieyès (2009, p. 82-83) diccionou que:

Conhecemos o verdadeiro objetivo de uma assembleia nacional: não é feita para se ocupar dos assuntos particulares dos cidadãos. Ela considera-os como uma massa [...]. Tiremos a consequência natural: que o direito de fazer-se representar só pertence aos cidadãos por causa das qualidades que lhes são comuns e não devido àquelas que os diferenciam. As vantagens pelas quais os cidadãos diferem estão além do caráter do cidadão. As desigualdades de propriedade e de indústria são como as desigualdades de idade, de sexo, de tamanho etc. Não desnaturam a igualdade cívica. [...] essas vantagens particulares estão sob a salvaguarda da lei; [...] cabe ao legislador criar vantagens desta natureza, dar privilégios a alguns e negá-los a outros. A lei não concebe nada; protege o que existe até o momento em que o que existe começa a prejudicar o interesse comum. [...]; todos os cidadãos, sem exceção, estão à mesma distância [...] e ocupam nela lugares diferentes; todos dependem igualmente da lei. 
Sieyès não foi um utópico por utópico. Da asserção citada, conseguimos perceber que ele assume saber que o parlamento não foi feito para tratar de assuntos particulares das pessoas. A vida corre muito depressa, todos os dias, inúmeras pessoas morrem, outras nascem. De fato, um parlamento cuida de questões gerais e vê mesmo todos os cidadãos como sendo uma coisa: massa. Sieyès não é contra essa generalização legislativa. $O$ problema está, segundo ele, no fato de os poderosos, além de enxergarem o povo como uma massa, manobrarem tal massa em um plasma de realizações apenas de seus interesses.

A grande questão, suscitada por Sieyès, é que não é porque é impossível que o Estado cuide de todos os cidadãos, atendendo aos seus particulares desejos, que esse Estado pode privilegiar alguns cidadãos. É impraticável que todos tenham as mesmas coisas, trabalhem em iguais profissões, vistam as mesmas roupas etc., mas é plenamente possível que todos tenham acesso a médicos em hospitais públicos sempre que precisarem, a bons professores e estrutura adequada nas escolas e universidades, a dignos salários, a casas para viver, em resumo, ao mínimo necessário para ser/estar feliz.

Ao lado de tudo isso, cremos que seria plenamente factível que tanto o "Homem Direito" parasse de obedecer às normas por pensar apenas em si e em seu próprio bem, como que o "Homem do Direito" parasse de produzir e reproduzir o Direito também motivado apenas por seus próprios interesses. Cremos, sim, ser preciso, às vezes e em alguns aspectos, que pensemos em nós mesmos, mas o pensar (no) coletivo é o ideal de vida. Um bom marido ou companheiro(a) e um bom pai, por exemplo, precisa essencialmente amar a si próprio em primeiro lugar, pois como amaria sua esposa, seu/sua companheiro(a) ou seu filho se não amar a si mesmo? Um bom cidadão precisa, no fundo, pensar em si, posto que se não se importar consigo mesmo como cuidará de terceiros? Como bem anota Delruelle, comentando a filosofia grega socrática:

\footnotetext{
A preocupação ética com o si é indissociável da preocupação política, com a cidade. Um cidadão que não cuide de si mesmo, do seu pensamento, da sua alma, arrisca-se a dar pouca atenção ao interesse geral. Cuidar de si é, ao refletir sobre si mesmo, examinar o que é ou não importante na vida e determinar o verdadeiro valor das coisas (2004, p. 43).
}

Entretanto, pensamos também ser possível além de pensarmos em nós, sermos também coletivistas. Qual seria o erro de pensar nos outros? É ruim ou feio ajudar o próximo? Fazer leis que beneficiem o povo (os pobres), dar-lhe saneamento básico, casas populares, escolas, creches etc., ao invés de roubar ou malversar verbas públicas dói na 
alma? Por que não se faz isso? Por que a maioria dos homens públicos rouba dinheiro público se morrerão como todos? Como se explica alguém querer muito dinheiro para viver uma vida de pouco mais de 70, 80 anos de duração?

Nossa reflexão terminativa é uma pergunta: por que o homem não se une ao seu semelhante para juntos vencerem as dificuldades da vida se a união é uma necessidade humana? Isso posto que "até a mais imoral das políticas não pode furtar-se a uma certa dinâmica coletiva" (DELRUELLE, 2004, p. 50), ou seja, até bandidos para roubarem um banco precisam de uma equipe organizada, com várias pessoas unidas! Por que o homem não se une para fazer o bem? Sim, todos os homens (?). Sabemos, é utopia! Mas, sonhemos.

\section{Considerações Finais}

O objetivo deste artigo, em sede de revisão bibliográfica qualitativa, foi servir como suporte para breves tessituras sobre o egoísmo humano atual, notadamente no contexto da dita "Ciência" Jurídica. Com suporte em ideias de autores diversos, buscou-se nas páginas precedentes tratar sobre exemplos de egoísmos do Homem do Direito, o profissional do Direito, e do Homem Direito, o cidadão comum que decide cumprir as leis por conforto próprio.

Após todo o esposado, conclui-se que os Homens Direitos e os Homens do Direito do presente século são indiscriminadamente egoístas, pois somente pensam em si. Sabemos que o expresso nas linhas anteriores incomoda muitas pessoas, pois a verdade é assim mesmo, ela incomoda, machuca, vai de encontro ao estabelecido, ao normal. Porém, ratificamos todo o dito. Pode o artigo ter fugido dos padrões científicos filosóficos, da linguagem jurídica culta, todavia assumimos, sem melindre, que nosso singelo escopo foi, mesmo que por meio de simplórias divagações, lembrar ao leitor que o Direito atual e as suas personagens ainda são muito egoístas e é necessário mudar isso!

Por final, então, pregamos que se viva como quis Sócrates, ou seja, vivendo de acordo consigo mesmo - viver bem. Viver, porém, sem destruir o outro - usando o Direito, por exemplo, para tal. Viver se permitindo ser alterado pelo outro, com ele aprender, ensinar-lhe. Viver e praticar algumas ações sem interesse algum, apenas por amor ao outro, por amor à vida. Por encantamento pela existência, que é única, irrepetível e incrível. 


\section{Referências}

ABREU, Leonardo Lani de. A construção social do Estado de exceção. Rio Branco: IV Encontro Regional Norte de História da Mídia (Universidade Federal do Acre), 2016. (Comunicação Oral).

ABREU, Leonardo Lani de. Grupo e crença: análise de discurso de representações sociais sobre norma e poder na internet brasileira. In: XXIV Congresso Nacional de Pesquisa e Pós-graduação em Direito, 24, 2015, Florianópolis. Anais do XXIV CONPEDI Sociologia, antropologia e cultura jurídicas, Florianópolis, p. 134-158. Disponível em:<http://www.conpedi.org.br/publicacoes/66fs1345/iy7q98vn/c7VO1693DdeEt7wi.pdf > . Acesso em: 10 fev. 2018.

AFRICA DO SUL. Constituição da República da África do Sul de 1996. Disponível em: $<$ http://www.conteudojuridico.com.br/vade-mecum-estrangeiro,constituicao-da-republicada-africa-do-sul-constitution-of-the-republic-of-south-africa,21415.html>. Acesso em: 10 fev. 2018.

BRASIL. Constituição da República Federativa do Brasil de 1988. Brasília: Congresso Nacional, 1988. Disponível em:

<http://www.planalto.gov.br/ccivil_03/constituicao/constituicaocompilado.htm>.Acesso em: 10 fev. 2018.

DELRUELLE, Edouard. Metamorfoses do sujeito: a ética filosófica de Sócrates a Foucault. Lisboa: Instituto Piaget, 2004.

FOUCAULT, Michel. A ordem do discurso: aula inaugural no Collège de France, pronunciada em 2 de dezembro de 1970. Tradução de Laura Fraga de Almeida Sampaio. 24. ed. São Paulo: Loyola, 2014.

KUJAWSKI, Gilberto de Mello. Prefácio. In: MINARDI, Inês. A elite possível: congresso constituinte de 1988. São Paulo: Expressão e Arte, 2007, p. 13-17.

SANTOS, Boaventura de Sousa. A crítica da razão indolente. São Paulo: Cortez, 2001.

SCHOPENHAUER, A. $O$ mundo como vontade e representação. Rio de Janeiro: Contraponto, 2001.

SENA, Eberson Dias. Concepção de homem em Do contrato social de Rousseau, Revista Pandora Brasil, São Paulo, n. 34, set. 2011, p. 79-86. Disponível em: <http://revistapandorabrasil.com/revista_pandora/filosofia_34/erberson.pdf> Acesso em: 10 fev. 2018.

SIEYÈS, Joseph Emmanuel. A constituinte burguesa. Tradução de Norma Azevedo. 5. ed. Rio de Janeiro: Editora Lúmen Juris, 2009. 